\title{
EPIDEMIOLOGICAL PANORAMA OF ORTHOPEDIC SPINE PATHOLOGY IN MEXICO
}

\author{
PANORAMA EPIDEMIOLÓGICO DA PATOLOGIA ORTOPÉDICA DA COLUNA \\ ESPINAL NO MEXICO
}

\section{PANORAMA EPIDEMIOLÓGICO DE LA PATOLOGÍA ORTOPÉDICA DE COLUMNA} VERTEBRAL EN MÉXICO

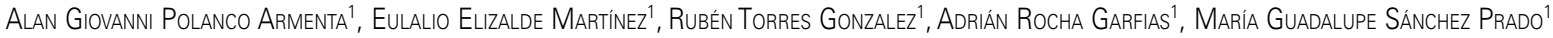 \\ 1. Instituto Mexicano del Seguro Social, High Specialty Medical Unit “Dr. Victorio de la Fuente Narváez", Hospital de Ortopedia, Department of Orthopedic Spine Surgery, \\ Mexico City, Mexico.
}

\begin{abstract}
Objective: To determine the epidemiology of orthopedic spine pathology in a national reference hospital in Mexico. Methods: Retrospective, observational and cross-sectional study, using the database and hospitalization census of the orthopedic spine service from January 2009 to December 2016. The data analysis was performed with SPSS version 22 measuring the central frequency and percentages. The demographic variables age and sex, and those related to the diagnosis, type of pathology, affected segment and degrees of affection were obtained. The sampling technique was non-probabilistic sampling by convenience of consecutive cases. Results: We analyzed 7,771 cases: $50.34 \%$ males, with a mean age of 53.51 years. The prevalence of the most frequent diseases in hospitalized patients was stenosis of the lumbar canal with $25.85 \%$ (1,834 patients), followed by lumbar disc herniation (23.12\%), spondylolisthesis (22.63\%), cervical spondylotic myelopathy (8.76\%), lumbar pain and lumbosciatalgia (4.10\%), cervical disc herniation (3.96\%), primary infection (3.80\%), loosening of material $(3.16 \%)$, spinal tumors (2.53\%) and cervical instability (2.04\%). Conclusions: This is the largest series of cases of spinal pathology treated in a hospital in Latin America. The most frequent condition was the stenosis of the lumbar canal, the most affected segment was the lumbar, and the most affected age group was 51 to 60 years. The estimate is an increase in the incidence of spinal diseases, so it is necessary to identify the risk factors and the behavior of each disease for its prevention. Level of Evidence IV; Retrospective, observational and descriptive study.
\end{abstract}

Keywords: Spondylolisthesis; Herniated disc; Compression, spinal cord; Epidemiology.

\section{RESUMO}

Objetivo: Determinar a epidemiologia da patologia da coluna ortopédica em um hospital de referência nacional no México. Métodos: Um estudo retrospectivo, observacional e transversal, utilizando o banco de dados e o recenseamento hospitalar do serviço de orelha ortopédica de janeiro de 2009 a dezembro de 2016. A análise de dados foi realizada através da SPSS versão 22 usando medidas de frequência central e porcentagens. As variáveis demográficas idade e gênero, e aqueles relacionados ao diagnóstico, tipo de patologia, segmento afetado e graus de carinho foram obtidos. A técnica de amostragem foi por conveniência e não probabilística de casos consecutivos. Resultados: Analisamos 7771 casos: 50,34\% do sexo masculino, com idade média de 53,51 anos. A prevalência das doenças mais frequentes em pacientes hospitalizados foi a conduta lombar estreita, com 25,85\% (1834 pacientes), seguida de hérnia de disco lombar (23,12\%), espondilolistese (22,63\%), mielopatia espondilótica cervical (8,76\%), lombo e lomossocialgia (4,10\%), hérnia de disco e infecção primária cervical (3,96\%, 3,80\%), afrouxamento do material (3,16\%), tumores espinhais $(2,53 \%)$ e instabilidade cervical (2,04\%). Conclusões: Este é o maior número de casos da patologia da coluna com tratamento hospitalar na América Latina. O estado mais comum era o canal lombar da coluna vertebral, o segmento lombar é o mais afetado e o grupo de idade mais afetado é de 51 a 60 anos. Um aumento na incidência de doenças da coluna vertebral está previsto, de modo que é necessário identificar os fatores de risco e o comportamento de cada condição para a prevenção. Nível de Evidência IV; Estudo retrospectivo, observacional e descritivo.

Descritores: Spondylolistésia; Hérnia discal; Compressão da medula espinhal; Epidemiologia.

\section{RESUMEN}

Objetivo: Conocer la epidemiologia de la patología ortopédica de columna vertebral en un hospital de referencia nacional en México. Métodos: Se realizó un estudio retrospectivo, observacional y transversal, utilizando la base de datos y censos de hospitalización del servicio de columna ortopédica de enero de 2009 a diciembre de 2016. Se realizó el análisis de datos mediante SPSS versión 22, utilizando medidas de frecuencia central y porcentajes. Se obtuvieron las variables demográficas edad y sexo, y las relacionadas con el diagnóstico, tipo de patología, segmento afectado y grados de afección. La técnica de muestreo fue por conveniencia y no probabilística de casos consecutivos. Resultados: Se analizaron 7.771 casos: 50,34\% del sexo masculino, con un promedio de edad de 53,51 años. La prevalencia de las enfermedades más frecuentes en los pacientes hospitalizados fue el conducto lumbar estrecho

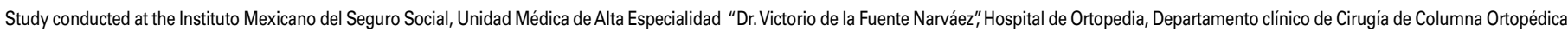
Correspondence: Avenida Colector n 15, Colonia Magdalena de las Salinas, delegación Gustavo A. Madero, Ciudad de México. alan.giovanni.polar@gmail.com 
con 25,85\% (1.834 pacientes), seguido de hernia discal lumbar (23,12\%), espondilolistesis (22,63\%), mielopatía espondilótica cervical (8,76\%), lumbalgias y lumbociatalgias (4,10\%), hernia discal cervical (3,96\%), infección primaria (3,80\%), aflojamiento de material $(3,16 \%)$, tumores espinales (2,53\%) e inestabilidad cervical (2,04\%). Conclusiones: Esta es la mayor serie de casos de patología de columna con tratamiento hospitalario en América Latina. El padecimiento más frecuente fue el conducto lumbar estrecho, el segmento más afectado el lumbar, y el grupo etario más aquejado el de 51 a 60 años. Se predice un incremento en la incidencia de las enfermedades de columna vertebral, por lo que es necesario identificar los factores de riesgo y el comportamiento de cada padecimiento para su prevención. Nivel de Evidencia IV; Estudio retrospectivo, observacional y descriptivo.

Descriptores: Espondilolistesis; Hernia discal; Compresión de la medula espinal; Epidemiología.

\section{INTRODUCTION}

There has been an increase in the number of patients with chronic spine disease, with elevated morbidity and mortality rates. ${ }^{1-3}$ Most of the patients are young working adults, which generates a great economic loss for society and for the country. There is little evidence of the prevalence of orthopedic spine pathology in the world literature. ${ }^{4-7}$ Patients with spine disease are a group that requires special attention for their treatment and rehabilitation due to the high costs that they generate in the medical, economic, and social spheres. ${ }^{8-11}$ They are patients that pose a significant health problem in Mexico due to the fact that they require prolonged hospitalizations, often several surgical procedures, and the recovery period is long, which means more consultations, lost work time, and the employment of relatives as caretakers during their recovery. ${ }^{12-15}$ The objective of our study was to identify the prevalence of orthopedic spine pathology in a national reference center from 2009 to 2016.

\section{METHODS}

A retrospective, cross-sectional, observational epidemiological study was conducted of patients admitted to the clinical department of spine surgery of the High Specialty Medical Unit "Dr. Victorio de la Fuente Narváez" in Mexico City.

The sample consisted of patients with spine pathology of orthopedic origin who received hospital treatment during the time period from January 2009 to December 2016. All patients admitted for treatment who were systematically registered in the medical records and censuses of the service were included. For the selection criteria, we considered all male and female patients of any age who received medical care and who were admitted to the spine service for medical or surgical management during the established time period.

For each case, patient variables (age, sex) and those related to the diagnosis, the type of pathology, the segment affected, and the different degrees of injury were obtained. A non-probabilistic sampling by convenience of consecutive cases technique was used.

SPSS ${ }^{\circledR}$ version 22 software was used for arithmetic and statistical calculations.

This study did not require informed consent because it was retrospective, descriptive, observational and non-interventional, safe, with lower than the minimum risk according to the norm that establishes the provisions for research in health of the Mexican Social Security Institute, based on those set forth in the General Health Law, published in the Official Gazette of the Federation on 7 February 1984 and its amendments, article 2 section VII, article 41 bis, and Title Five Sole Chapter. All the data obtained from the database were used only by the research team in a manner that protected the confidentiality and identity of the patient. This research study complies with the International Norm of the Declaration of Helsinki of the 18th World Medical Association General Assembly, Helsinki, Finland, June 1964 and the General Assembly, Fortaleza, Brazil, 2012; with the regulation of the General Health Law with regards to health research currently in force and with the fundamental principles of bioethics: beneficence, non-maleficence, justice, self-determination or autonomy; as well as with the research standards of the IMSS and the approval of the Institutional Review Board under registration number R-2017-34-01-36.

\section{RESULTS}

A total of 7,771 cases with spine pathology who were admitted for hospital treatment between 1 January 2009 and 31 December 2016 were analyzed, of whom 4,119 (53\%) were male with an average age of 53.51 years, a mean of 51 and a median of 64 . Figure 1 shows the distribution by sex, with a male to female ratio of approximately 1.12:1. The average number of days in the hospital was 5.7, mean 4, median 5. (Figure 1)

It was determined that, of the cases reviewed, most fell into the 51 to 60 years of age range with 2,389 patients $(30,74 \%)$, followed by 41 to 50 with $16.92 \%$, and 61 to 70 with $14.76 \%$. (Figure 2)

We found that the year with the highest number of admissions for hospital treatment was 2016 with 1,153 cases (14.83\%), followed by 2013 with $13.89 \%$, and 2011 with $12.72 \%$. (Figure 3)

The most frequent pathology was stenosis of lumbar canal at $25.85 \%$ (1,834 patients), followed by herniated lumbar disc (23.12\%), spondylolisthesis (22.63\%), cervical spondylotic myelopathy (8.76\%), lumbar pain and lumbar sciatic pain (4.10\%), herniated cervical disc $(3.96 \%)$, primary infection $(3.80 \%)$, loosening of material $(3.16 \%)$, spine tumors (2.53\%), and cervical instability (2.04\%). (Figure 4)

\section{DISCUSSION}

There are not enough data to determine the impact of orthopedic spine pathologies on the population in our country, information that could assist in designing proposals for prevention and therapeutic approaches. ${ }^{1}$

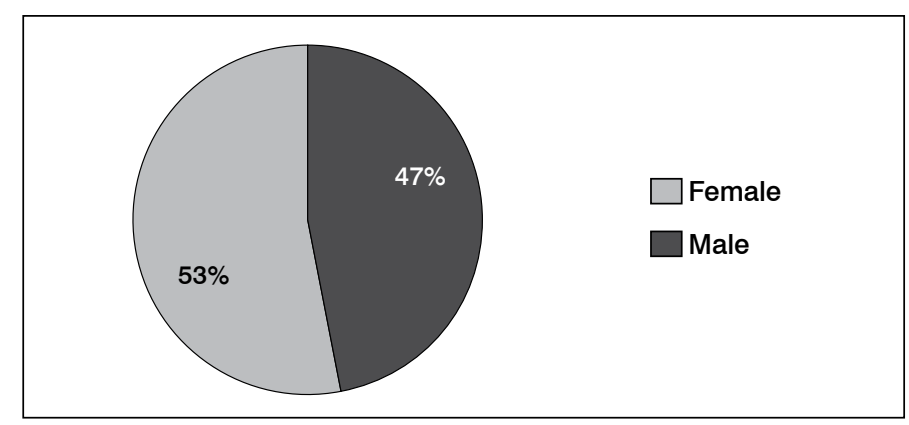

Figure 1. Distribution by sex.

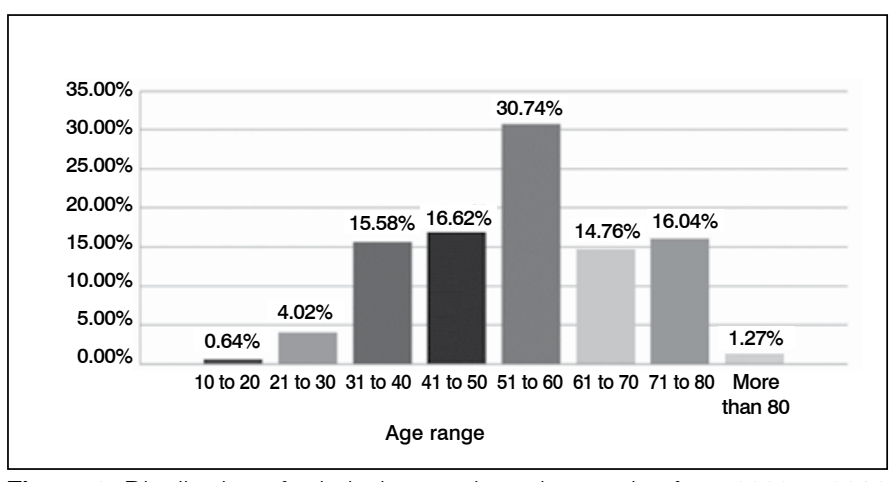

Figure 2. Distribution of admissions to the spine service from 2009 to 2016 by age range. 


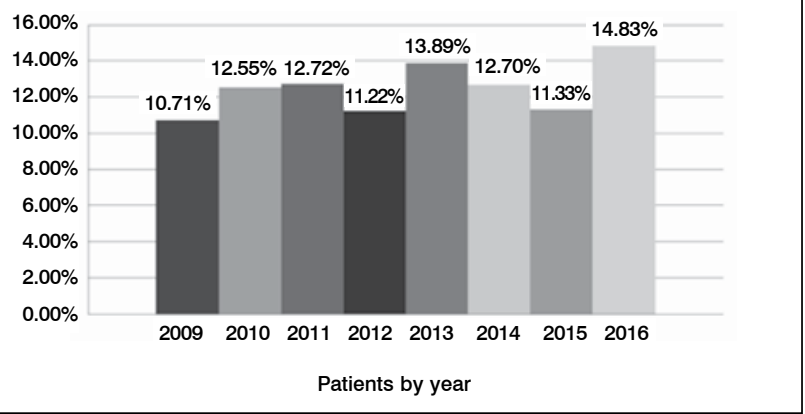

Figure 3. Distribution of admissions to the spine service from 2009 to 2016 by age range.

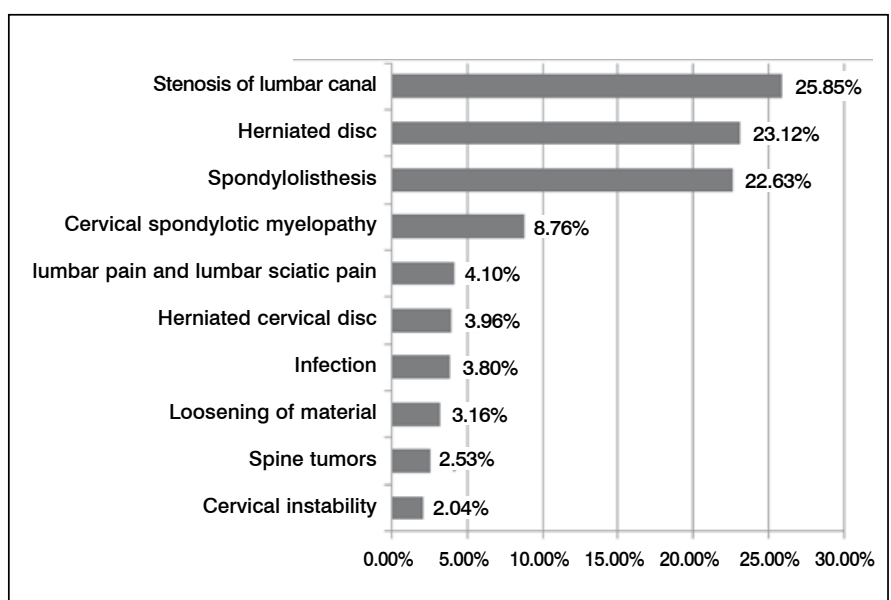

Figure 4. Distribution of patients treated by year, from 2009 to 2016.

The natural evolution of the stenosis of lumbar canal is not well understood, ${ }^{16-18}$ since there have been no prospective longitudinal studies conducted in which the evolution has been documented. A review of existing publications indicates that around $20 \%$ of patients experience progression of the symptoms, ${ }^{19}$ the morbidity and mortality rates increase with age, and complications are more common in elderly patients. ${ }^{20-22}$ This condition is not sex-dependent. The most affected age ranges in our study were from 46 to 65 years of age, which agrees with those reported by previous studies. ${ }^{23-25}$

Among the pathologies reviewed in this study, we did not observe a significant increase in the number of cases of disc herniation during the period from 2009 to 2016 . The prevalence of this pathology is constant in men and women, though significantly higher in men at $56.98 \%$. The most affected age group was from 30 to 50 years of age. The lumbar segment was the most affected and, as such, is a relevant characteristic in hospital care. The most affected level was L4-L5, with L5-S1 in second place, which corresponds to findings reported in the literature. ${ }^{12,13,15}$

We determined that there was no significant increase in the number of cases of spondylolisthesis during the period from 2009 to 2016. Its prevalence is higher in women. The age range with the highest presentation is from 46 to 65 years. Most cases reported affected level L5. As expected, the prevalence of spondylolisthesis showed an increase among the older age groups, those from 46 to 65 years of age, indicating that this pathology has a higher incidence due to older age. The most affected level was L4-L5, followed by L5-S1. In our study there was a higher incidence among women, which agrees with the literature, but the trend was not as high as that reported. We found that $64 \%$ of the women and $41 \%$ of the men were affected. ${ }^{9,16}$

It is reported that cervical spondylotic myelopathy is the most frequent cause of myelopathy in adults over 55 years of age. In our study, the number of cases of cervical spondylotic myelopathy increased in 2016. It was more common in men, with a gradual increase with age to a maximum peak between 56 and 75 years of age, causing progressive disability and deterioration of the quality of life, which agrees with the literature. ${ }^{26,27}$

We observed a prevalence of herniated cervical disc in 135 cases $(3.96 \%)$ which is lower than the $5.5 \%$ prevalence reported in previous studies. The most frequently affected level was C6-C7 (60\%), followed by C5 - C6 (20\%) and C4 - C5. ${ }^{12,13,15}$

It is difficult to determine the exact prevalence of lumbar pain as a health issue because only a part of the population with this problem is treated in this unit. However, the international literature suggests that the prevalence of lumbar pain has not changed significantly over that last 30 years. In our study, the age ranges reported went from 15 to 82 years, with the maximum peak of 36 to 45 , but our sample was not representative of this pathology in that we only reported cases that required hospital management.

The reporting of tumors in this study was made by taking data from 8 years of medical records, but the number of patients was not significant given that most were metastatic tumors and because of the small number of patients identified. The difference between the sexes is not at all representative, since this type of pathology is treated the bone tumor service of the unit.

The registry of patients diagnosed with primary infections was made up of those with diagnoses of osteomyelitis, spondylodiscitis, and Pott disease, but because we are a specialty hospital, only patients with these pathologies are treated and were included in the group of infections.

\section{CONCLUSIONS}

It can be concluded that in Mexico there are no records that clearly document the magnitude, class, and frequency of orthopedic spine pathologies present in the population; likewise for the number of patients, the prolonged period of disability, hospitalization time, and the time invested caring for these diseases. The various spine pathologies incur high institutional and social economic costs.

To the extent that we can identify the risk factors that contribute to these pathologies and make more timely diagnoses, we can develop strategies that will allow us to reduce the intensity of the sequelae, as well as disabilities in future generations. It also allows us to identify the population groups at high risk for these pathologies in order to determine the circumstances that produce them. With this information, we can develop protocols and take measures to prevent and avoid complications as much as possible.

Taking the individual and social costs of each of these pathologies into account, new studies based on epidemiological evidence can be designed, focused on investigating risk factors and treatments with the goal of improving health services.

\section{ACKNOWLEDGEMENTS}

My deepest thanks and recognition to Dr. Alan Manuel Polanco Sánchez for his great knowledge and advice on the subject that allowed us to complete this research.

All authors declare no potential conflict of interest related to this article.

CONTRIBUTION OF THE AUTHORS: Each author made significant individual contributions to this manuscript. AP (0000-0002-8530-0250) and EE (0000-0002-5397-3557)* were the main contributors to the compilation of the bibliography, the writing of the paper, and the analysis. AP and MS (0000-0003-4923-6690) were responsible for reviewing the patient records to create the database. MS reviewed the clinical case files for populating the database. AR (0000-0002-0344-629X)* and RT (0000-0001-5662-8356)* conducted the final review and approval of the article. *ORCID (Open Researcher and Contributor ID). 


\section{REFERENCES}

1. Zeitoun D, Hajj FEI, Sariali E, CatonnéY, Pascal-Moussellard H. Evaluation of spinal cord compression and hyperintense intramedullary lesions on T2-weighted sequences in patients with cervical spondylotic myelopathy using flexion-extension MRI protocol. 2015;15(4):668-74.

2. Duruflé A, Pétrilli S, Le Guiet JL, Brassier G, Nicolas B, Le Tallec H, et al. Cervical spondylotic myelopathy in athetoid cerebral palsy patients: about five cases. 2005;72(3):270-4

3. Klineberg E. Cervical Spondylotic Myelopathy: A Review of the Evidence. Orthop Clin NA. 2010:41(2):193-202.

4. Matz PG. Does nonoperative management play a role in the treatment of cervical spondylotic myelopathy? Spine J. 2006;6(6 Suppl):175S-81S.

5. Bapat MR, Chaudhary K, Sharma A, Laheri V. Surgical approach to cervical spondylotic myelopathy on the basis of radiological patterns of compression: prospective analysis of 129 cases. Eur Spine J. 2008;17(12):1651-63.

6. Siemionow KB, Neckrysh S. Anterior Approach for Complex Cervical Spondylotic Myelopathy. Orthop Clin North Am. 2012;43(1):41-52.

7. Guo $Q$, Zhang M, Wang $L$, Lu X, Ni B. Deep surgical site infection after anterior decompression and fusion with plate fixation for cervical spondylotic radiculopathy or myelopathy. Clin Neurol Neurosurg. 2016;141:13-8.

8. Karadimas SK, Su E, Yu W, Satkunendrarajah K, Kallitsis JK, Gatzounis G, et al. A novel experimental model of cervical spondylotic myelopathy ( CSM ) to facilitate translational research. Neurobiol Dis. 2013;54:43-58.

9. Li F, Chen Z, Zhang F, Shen H, Hou T. A meta-analysis showing that high signal intensity on T2-weighted MRI is associated with poor prognosis for patients with cervical spondylotic myelopathy. J Clin Neurosci. 2011;18(12):1592-5.

10. Arnts $\mathrm{H}$, Bartels $\mathrm{RH}$. Flexible dropped head deformity following laminectomy for cervical spondylotic myelopathy: a case series and review of literature. Spine J. 2016;16(10):e721-4.

11. Yuan S, ZouY, LiY, Chen M, YueY. A clinically relevant MRI grading system for lumbar central canal stenosis. J Clin Imaging. 2016;40(6):1140-5.

12. Aydogan M, Ozturk C, Mirzanli C, Karatoprak O, Tezer M, Hamzaoglu A. Treatment approach in tandem (concurrent) cervical and lumbar spinal stenosis. Acta Orthop Belg. 2007;73(2):234-7.

13. Lee SY, Kim T, Oh JK, Lee SJ, Park MS. Lumbar Stenosis: A Recent Update by Review of Literature. Asian Spine J. 2015;9(5):818-28.

14. Trouillier H, Birkenmaier $\mathrm{C}$, LKluzik J, Kauschke T, Refior HJ. Operative treatment for de- generative lumbar spinal canal stenosis. Acta Orthop Belg. 2004;70(4):337-43.

15. Rosales LM, Manzur D, Miramontes V, Alpízar A, Reyes-sánchez AA. Conducto lumbar estrecho. Acta Médica Grupo Ángeles. 2006;4(2):101-10.

16. Montalvo BM, Quencer RM, Brown MD, Sklar E, Post MJ, Eismont F, et al. Lumbar Disk Herniation and Canal Stenosis: Value of Intraoperative Sonography in Diagnosis and Surgical Management. AJNR Am J Neuroradiol. 1990;11(1):31-40.

17. Truszczyńska A, Drzał-Grabiec J, Trzaskoma Z, Rąpała K, Tarnowski A, Górniak K. A Comparative Analysis of Static Balance Between Patients With Lumbar Spinal Canal Stenosis and Asymptomatic Participants. J Manipulative Physiol Ther. 2014; 37(9):696-701.

18. YasuharaT, TakahashiY, Kumamoto S, Nakahara M, Yoneda K, NiimuraT, et al. Proximal Vertebral Body Fracture after 4-Level Fusion Using L1 as the Upper Instrumented Vertebra for Lumbar Degenerative Disease: Report of 2 Cases with Literature Review. Acta Med Okayama. 2013;67(3)197-202.

19. Omidi-kashani F, Hasankhani EG, Ashjazadeh A. Lumbar Spinal Stenosis: Who Should Be Fused? An Updated Review. Asian Spine J. 2014;8(4):521-30.

20. Hicks GE, Sions JM, Coyle PC, Pohlig RT. Altered spatiotemporal characteristics of gait in older adults with chronic low back pain. Gait Posture. 2017;55:172-6.

21. Snyder DL, Doggett D, Turkelson C. Treatment of Degenerative Lumbar Spinal Stenosis. Am Fam Physician. 2004;70(3):517-20.

22. Lee JA, Choi J, ChoiT, Hee J, Ha I, Lee M. Evaluation of the clinical application of a leaflet for clinical practice guidelines in patients with herniated intervertebral discs: a study protocol for a randomized controlled trial. Integr Med Res. 2016;5(2):161-4.

23. Jebaseelan DD, Jebaraj C, Yoganandan N, Rajasekaran S, Yerramshetty J. Biomechanical responses due to discitis infection of a juvenile thoracolumbar spine using finite element modeling. Med Eng Phys. 2014;36(7):938-43.

24. Montgomerie JZ. Infections in Patients with Spinal Cord Injuries. Clin Infect Dis. 1997;25(6):1285-90.

25. Rodríguez-Gárcia J, Sánchez-Gastaldo A, Ibáñez-Campos T, Vázquez-Sousa C, CantadorHornero M, Expósito-Tirado JA et al. Factores relacionados con la cirugía fallida de hernia discal lumbar. Neurocirugía. 2005;16(6)507-17.

26. Taylor C, Kumar R. Cervical spine disease and anaesthesia. Anaesth Intensive Care Med. 2011;12(6):225-8.

27. Walid MS, Robinson JS, Robinson ERM, Brannick BB, Ajjan M, Robinson JS. Comparison of outpatient and inpatient spine surgery patients with regards to obesity, comorbidities and readmission for infection. J Clin Neurosci. 2010;17(12):1497-8. 